\title{
SIMULASI SISTEM ANTRIAN PEMESANAN MAKANAN PADA RUMAH MAKAN DENGAN MENGGUNAKAN MODEL MULTI CHANNEL MULTI QUEUE
}

\author{
Jimmy Rio Tinambunan, Intan Savira, *Windania Purba, Siti Aisyah, Marlince NK Nababan, N P \\ Dharshinni \\ Program Studi Sistem Informasi Fakultas Teknologi dan Ilmu Komputer, Universitas Prima Indonesia \\ E-mail: *winda.nia04@gmail.com
}

\begin{abstract}
ABSTRAK - Antrian adalah sekumpulan proses dan mekanisme di dalam suatu sistem yang berkaitan dengan urutan (prioritas) yang dilakukan oleh sistem. Pelaku-pelaku utama dalam sebuah situasi antriaan adalah pelanggan (customer) dan pelayan (server). Dalam model antrian, interaksi antara pelanggan dan pelayan adalah menarik hanya dalam hal kaitannya dengan periode waktu yang diperoleh pelanggan untuk menyelesaikan sebuah pelayanan. Proses antrian dapat diterapkan dengan menggunakan beberapa sistem, antara lain Multi Queue Multi Channel (MQMC). Sistem ini paling sering dijumpai dalam kehidupan sehari - hari. Proses antrian di kasir supermarket, loket karcis stasiun, tiket film, dan sebagainya merupakan beberapa contoh penerapan sistem MQMC. Di dalam sistem MQMC, terdapat beberapa channel yang melayani beberapa antrian pada waktuyang bersamaan. Sistem ini merupakan sistem yang memiliki efisiensi waktu antrian tertinggi dari beberapa sistem yang ada, sedangkan kelemahannya adalah sistem ini akan sangat memboros biaya untuk jumlah item yang relatif sedikit. Dengan melihat pertimbangan di atas peneliti tertarik untuk membuat penelitian tentang simulasi menggunakan MQMC, hasil yang didapatkan bahwa MQMC dapat digunakan untuk mengetahui efesiensi dari proses antrian yang selama ini terjadi di rumah makan.
\end{abstract}

Kata kunci: Simulasi, Antrian, Model

\section{PENDAHULUAN}

Antrian adalah sekumpulan proses dan mekanisme di dalam suatu sistem yang berkaitan dengan urutan (prioritas) yang dilakukan oleh sistem. Dari sudut pandang model antrian, situasi antrian diciptakan dengan cara berikut ini. Sementara para pelanggan tiba di satu sarana pelayanan, mereka bergabung dengan sebuahantrian. Pelayan memilih seorang pelanggan dari antrian untuk memulai pelayanan. Setelah selesainya pelayanan, proses memilih pelanggan baru (yang sedang menunggu) diulangi. Diasumsikan tidak ada waktu yang terhilang antara penyelesaian pelayanan dengan diterimanya seorang pelanggan baru disarana pelayanan tersebut.

Pelaku-pelaku utama dalam sebuah situasi antriaan adalah pelanggan (customer) dan pelayan (server). Dalam model antrian, interaksi antara pelanggan dan pelayan adalah menarik hanya dalam hal kaitannya dengan periode waktu yang diperoleh pelanggan untuk menyelesaikan sebuah pelayanan. Jadi, dari sudut pandang kedatangan pelanggan, kita tertarik pada interval waktu yang memisahkan kedatangan yang berturut-turut. Juga, dalam kasus pelayanan, yang diperhitungkan adalah waktu pelayanan per pelanggan. Proses antrian dapat diterapkan dengan menggunakan beberapa sistem, antara lain sistem Single Queue Single Channel (SQSC), Single Queue Multi Channel (SQMC) dan Multi Queue Multi Channel (MQMC).

Di dalam sistem SQSS terdapat sebuah antrian dan sebuah channel untuk melayani antrian tersebut. Keunggulan dari sistem ini adalah biayanya murah karena hanya memiliki satu channel saja, sedangkan kelemahannya adalah waktu antrian dalam sistem akan memakan waktu cukup lama jika jumlah item banyak. Untuk mengatasi hal tersebut, maka dapat digunakan sistem SQMC. Dalam sistem SQMC terdapat sebuah antrian yang dilayani oleh beberapa channel. Masing-masing channel bekerja secara independent. Keunggulan dari sistem ini adalah efisiensi waktu antrian dalam sistem cukup tinggi namun masih kalah jika dibandingkan dengan sistem MQMC, sedangkan kelemahannya adalah sistem ini memakan biaya yang cukup besar (mahal) dalam hal penyediaan channel. Sistem lainnya adalah sistem MQMC. Sistem ini paling sering dijumpai dalam kehidupan sehari - hari. Proses antrian di kasir supermarket, loket karcis stasiun, tiket film, dan sebagainya merupakan beberapa contoh penerapan sistem MQMC. Di dalam sistem MQMC, terdapat beberapa channel yang melayani beberapa antrian pada waktu yang bersamaan. Sistem ini merupakan sistem yang memiliki efisiensiwaktu antrian tertinggi dari beberapa sistem yang ada, sedangkan kelemahannya adalah sistem ini akan sangat memboros biaya untuk jumlah item yang relatif sedikit.

Penulis tertarik untuk mempelajari sistem antrian MQMC sekaligus melihat penerapannya dalam kehidupan sehari-hari. Penulis memilih antrian pemesanan makanan pada cafe dengan pertimbangan bahwa kebanyakan orang pernah memesan makanan pada rumah makan ataupun cafe sehingga tentu saja mengenal dan tahu mengenai proses yang terjadi. Oleh karena itu, penulis mengambil skripsi dengan judul "Simulasi Sistem Antrian Pemesanan Makanan pada Rumah Makan dengan Menggunakan Model Multi Channel Multi Queue" 


\section{ISI PENELITIAN}

\subsection{Model dan Simulasi}

Yang dimaksud dengan model adalah suatu gambaran, abstraksi atau imajinasi dari suatu sistem nyata. Model juga dapat berarti suatu abstraksi dunia nyata yang dapat digunakan untuk mengambil keputusan[1]. Kegunaan-kegunaan dari model antara lain:

1. Membantu dalam berpikir, model menyajikan deskripsi yang sistematis tentang suatu sistem sehingga dapat mempermudah mempelajari sistem tersebut.

2. Membantu untuk berkomunikasi atau mempermudah menjelaskan tentang suatu sistem kepada orang lain.

3. Sebagai alat latihan, untuk melatih ketrampilan orang-orang yang berhubungan dengan sistem sebenarnya yang dimodelkan.

4. Sebagai alat prediksi terhadap kelakuan sistem untuk waktu yang akan datang, yaitu pengaruhpengaruh yang ingin diketahui jika ada perubahan sistem atau operasi sistem.

5. Membantu dalam melakukan percobaan.

\subsection{Antrian}

Antrian biasanya diibaratkan juga dengan menunggu atau menanti, antrian biasanya diartikan orang atau benda yang sedang dalam proses masa tunggu atau mengantri untuk mendapatkanpelayanan [2]. Fenomena menunggu adalah hasil langsung dari keacakan dalam operasi sarana pelayanan. Secara umum, kedatangan pelanggan dan waktu perbaikan tidak diketahui sebelumnya, karena jika dapat diketahui, pengoperasi sarana tersebut dapat dijadwalkan sedemikian rupa sehingga akan sepenuhnya menghilangkan keharusan untuk menunggu. Setiap antrian harus memiliki estimasi waktu yang baik sehingga proses antrian berjalan dengan lancar [3]. Jika didalam suatu pelayanan terjadi suatu antrian maka hal ini dinilai sangat kurang baik, hal ini dikarenakan terjadinya proses menunggu yang dialami oleh konsumen[4].

\subsection{Multi Queue - Multi Channel (MQMC)}

Multi Queue - Multi Channel (MQMC), yaitu sistem antrian dimana terdapat beberapa server yang digunakan untuk melayani beberapa antrian [3].

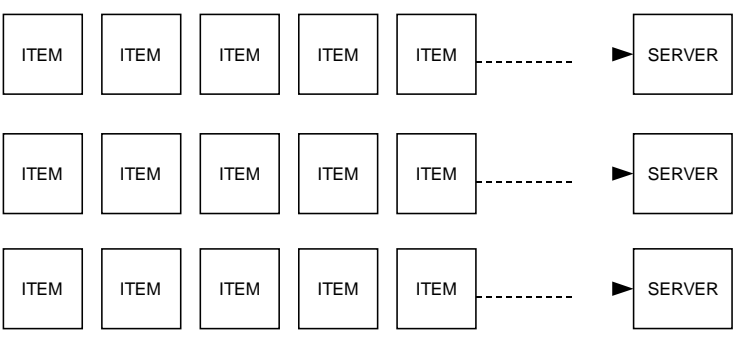

Gambar 1. Sketsa MQMC

\subsection{Analisa Sistem}

Perangkat lunak simulasi antrian ini menerapkan algoritma penjadwalan FIFO (First In First Out), yang berarti bahwa customer yang pertama masuk dalam antrian akan dilayani terlebih dahulu. Namun, jika ditinjau secara global dalam sistem, algoritma penjadwalan FIFO ini tidak berlaku, yang berarti bahwa customer yang pertama kali masuk ke dalam sistem, belum tentu pertama kali keluar dari sistem. Dalam proses perancangan perangkat lunak simulasi ini, penulis mengambil beberapa asumsi yaitu :

1. Waktu terkecil dalam perangkat lunak adalah detik.

2. Timer di-set per detik.

3. Customer yang sudah masuk dalam antrian tidak akan meninggalkan sistem sebelum selesai dilayani.

4. Jika terdapat beberapa meja dalam keadaan kosong, maka meja kosong dengan nomor indeks terkecil yang akan dipilih oleh customer.

5. Jumlah kasir terdiri dari dua buah yaitu satu untuk melayani customer yang memesan makanan untuk dibungkus pulang dan satu lagi untuk melayani customer yang makan di tempat.

Customer yang terdapat dalam sistem dimisalkan sebanyak 4 orang dengan perincianwaktu kedatangan (masuk ke dalam antrian) adalah sebagai berikut :

Tabel 1. Waktu Kedatangan Customer

\begin{tabular}{|c|c|c|c|c|}
\hline Server & 1 & 2 & 3 & 4 \\
\hline Waktu & $09: 18$ & $09: 20$ & $09: 23$ & $09: 25$ \\
(detik) & $: 85$ & $: 71$ & $: 45$ & $: 88$ \\
\hline
\end{tabular}

Keadaan awal yang sesuai dengan kondisi di atas dapat digambarkan pada gambar 2 .

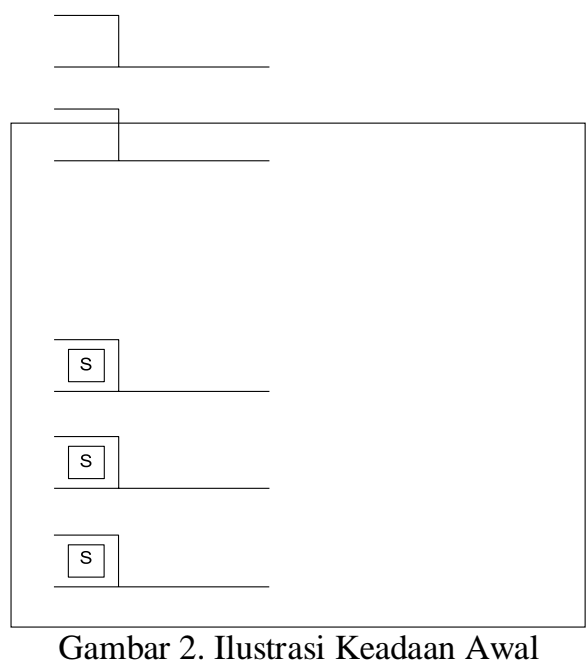

Keterangan :

$\mathrm{S}=$ Server

Customer-1 datang pada pukul $09: 18: 85$ dan akan dilayani pada waktu $09: 19: 70$. Ketiga 
server dalam keadaan idle. Sesuai dengan asumsi di atas, maka customer-1 masuk ke server-1. Customer1 selesai pada pukul $09: 22: 02$. Customer-2 datang pada pukul 09 : 20 : 71 dan masuk ke server-1. Customer-2 mulai dilayani pada waktu $09: 23: 00$ dan selesai pada pukul $09: 25$ :

63. Proses dilanjutkan untuk customer-3. Waktu kedatangan customer-3 adalah pukul $09: 23: 45$ dan akan masuk pada server-1. Customer-3 akan mulai dilayani pada waktu 09:26:05 dan selesai pada pukul $09: 28: 97$.

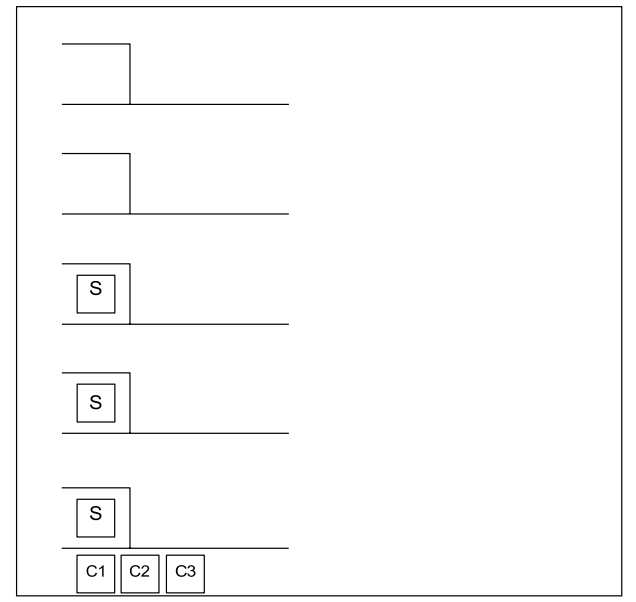

Gambar 3. Customer-1, 2 dan 3 Datang

Customer-4 datang pada pukul $09: 25: 88$ dan akan masuk ke server-1. Customer-4 akan memulai dilayani pada waktu 09 : 29 : 65 dan selesai pada pukul 09 : 33 : 03. Proses di atas akan dilanjutkan untuk customer berikutnya secara kontiniu. Untuk hasil laporan pengamatan dapat dilihat pada tabel 2 .

Tabel 2. Laporan Pengamatan

\begin{tabular}{|c|c|c|c|}
\hline \multirow{2}{*}{ Customer } & $\begin{array}{c}\text { Waktu } \\
\text { Datang }\end{array}$ & $\begin{array}{c}\text { Waktu } \\
\text { Mulai }\end{array}$ & $\begin{array}{c}\text { Waktu } \\
\text { Selesai }\end{array}$ \\
\hline 1 & $09: 18: 85$ & $09: 19: 70$ & $09: 22: 02$ \\
\hline 2 & $09: 20: 71$ & $09: 23: 00$ & $09: 25: 63$ \\
\hline 3 & $09: 23: 45$ & $09: 26: 05$ & $09: 28: 97$ \\
\hline 4 & $09: 25: 88$ & $09: 29: 65$ & $09: 33: 04$ \\
\hline
\end{tabular}

Perangkat lunak juga mampu mensimulasikan proses dimana terdapat banyakcustomer yang sedang menunggu dalam antrian. Misalkan diketahui suatu keadaan antrian seperti ditunjukkan oleh gambar 4 .

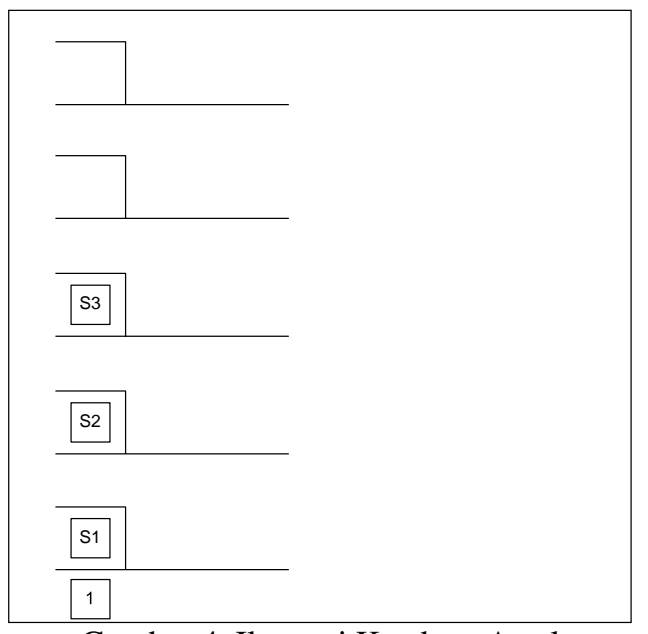

Gambar 4. Ilustrasi Keadaan Awal

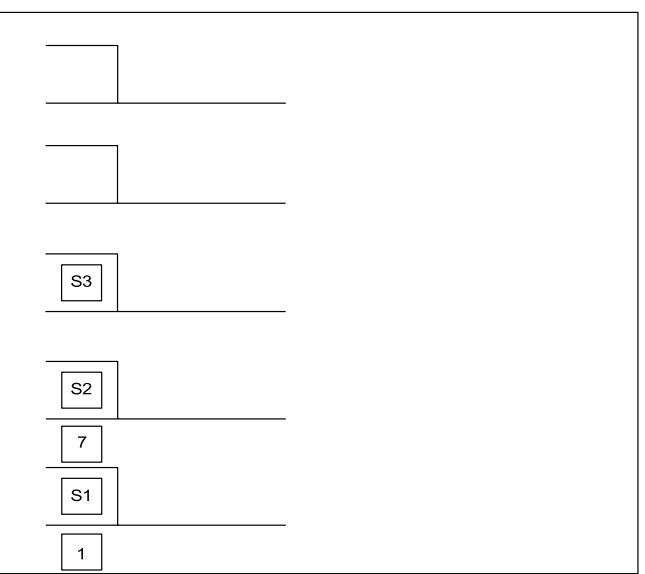

Gambar 5. Ilustrasi Customer-1 dan 7 Datang

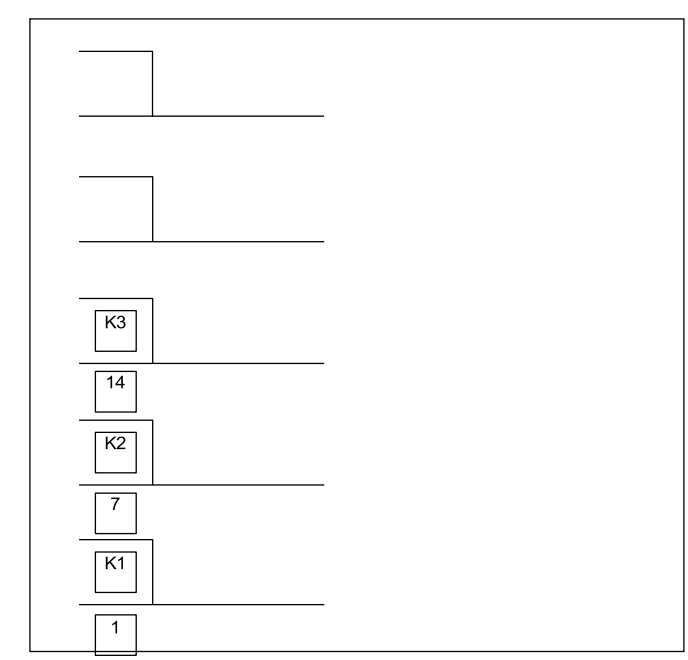

Gambar 6. Ilustrasi Customer-1, 7 dan 14 Datang 


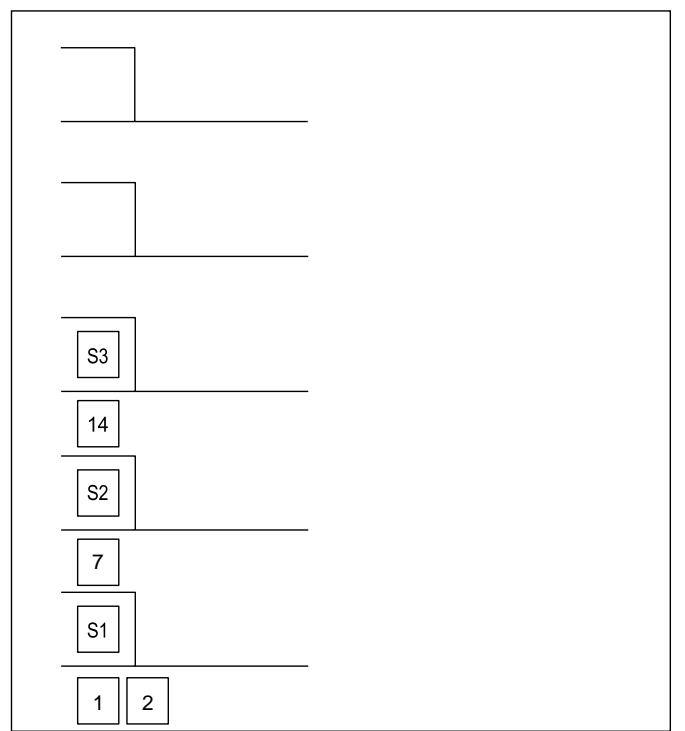

Gambar 7. Ilustrasi Customer-1, 2, 7 dan 14 Datang

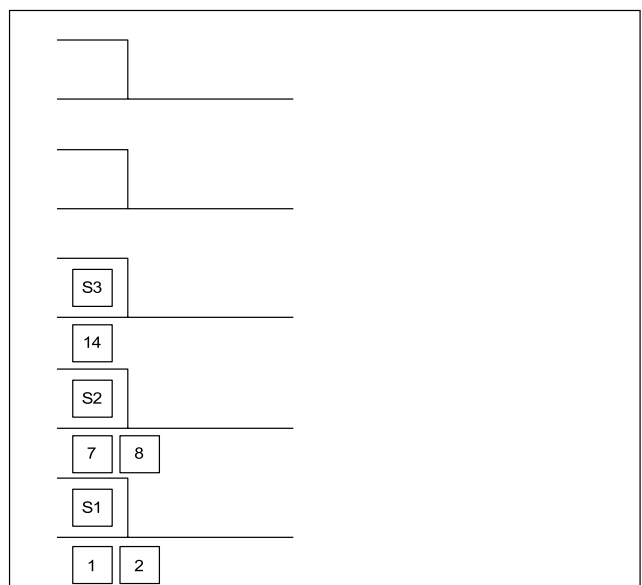

Gambar 8. Ilustrasi Customer-1, 2, 7, 8 dan 14 Datang

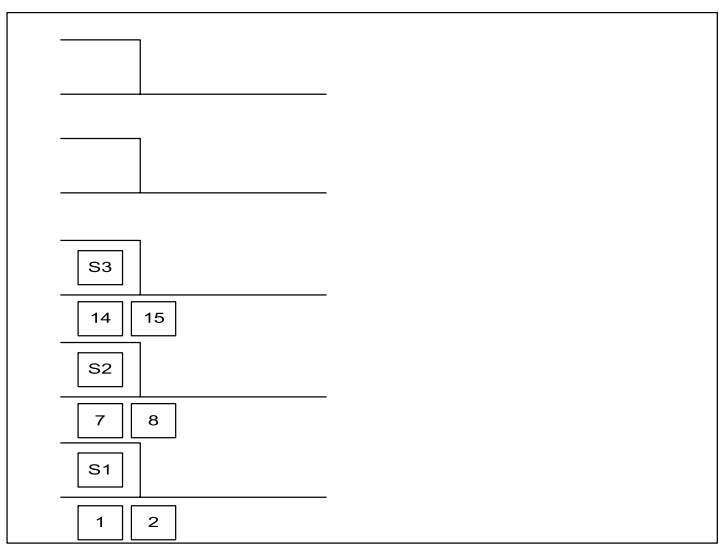

Gambar 8. Situasi Pertama

Proses kerja dari sistem simulasi ini dapat digambarkan seperti terlihat pada gambar 9 .

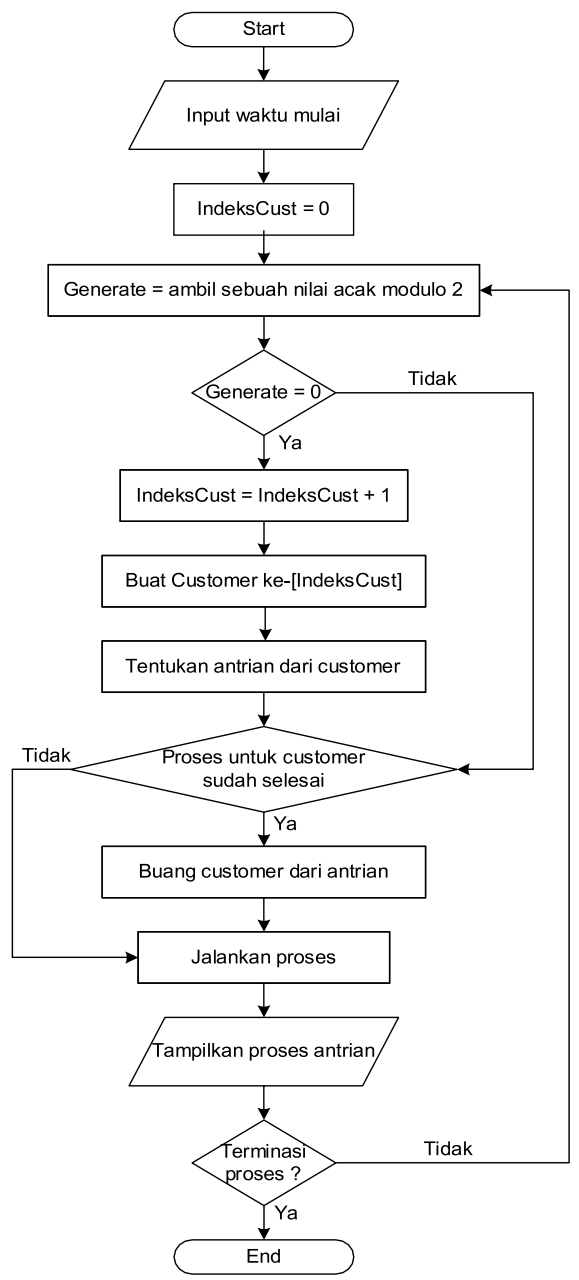

Gambar 9. Flowchart dari Proses

Secara garis besar, prosedur kerja dari sistem ini hampir sama dengan prosedur kerja dari sistem simulasi lainnya. Prosedur kerja sistem akan dimulai dari adanya kejadian kemunculan customer baru yang akan dilanjutkan dengan pengecekan apakah customer tersebut dapat diproses (dimasukkan ke dalam bilik komputer) atau harus di-pending (menunggu pada bariasan antrian) terlebih dahulu. Tentu saja, sistem juga harus memberikan alasanyang jelas terhadap hasil yang diberikan kepada pemakai. Sistem ini akan dijalankan hingga adanya intervensi pemakai untuk menghentikan sistem ataupun sistem memang telah selesai.

Prosedur kerja dari sistem akan dimulai dari proses penginputan jumlah server dan batas maksimal antrian. Kemudian, proses akan dilanjutkan dengan penentuan apakah ada customer baru yang masuk ke dalam sistem atau tidak. Proses penentuan ini akan dilakukan secara acak dengan persentase kedatangan sebesar $50 \%$. Apabila ada customer baru yang masuk, maka akan ditentukan lokasi antrian dari customer baru tersebut secara langsung. Setelah itu, maka customer tersebut akan bergerak menuju ke server yang telah ditentukan. Sedangkan, apabila seorang customer telah selesai dilayani, maka customer ini akan dihilangkan dari 
sistem. Terakhir, apabila ada proses terminasi / interupsi yang dilakukan oleh pemakai, maka perangkat lunak akan menghentikan proses dan keluar dari sistem.

Adapun tahapan dan langkah-langkah pengembangan perangkat lunak ini dapat digambarkan dalam bentuk diagram alir seperti diperlihatkan pada gambar 10 .

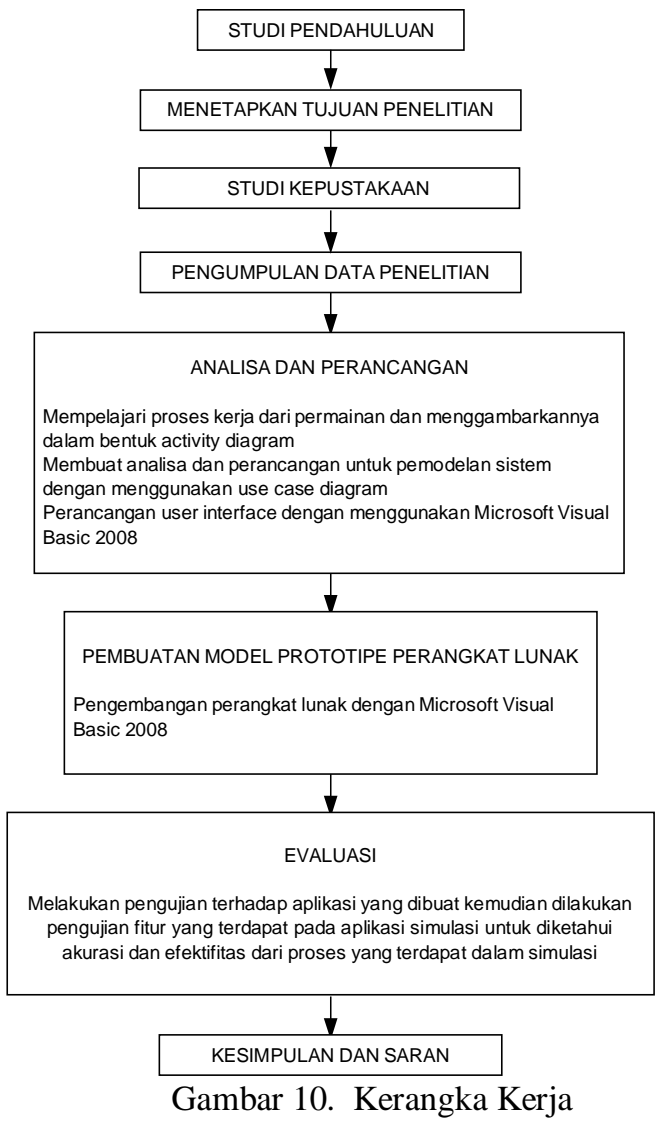

Model sistem yang dirancang pada penelitian ini dapat dilihat pada gambar berikut:

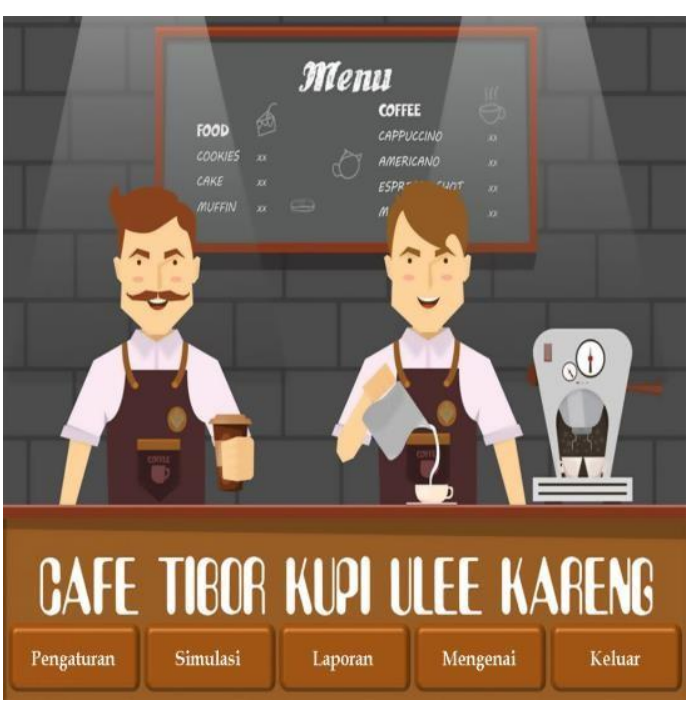

Gambar 11. Tampilan Utama/Awal
Untuk melakukan pengisian data keadaan awal simulasi, maka dapat mengklik link „Pengaturan ${ }^{\text {ee }}$ seperti terlihat pada gambar 12.

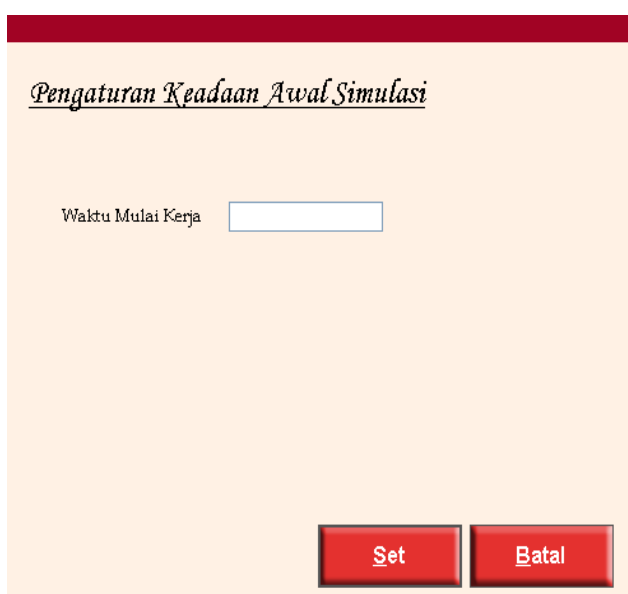

Gambar 12. Tampilan Pengaturan Waktu

Untuk menampilkan proses simulasi, maka dapat mengklik link ,Simulasi ${ }^{\text {ie }}$ sehingga akan ditampilkan form Simulasi

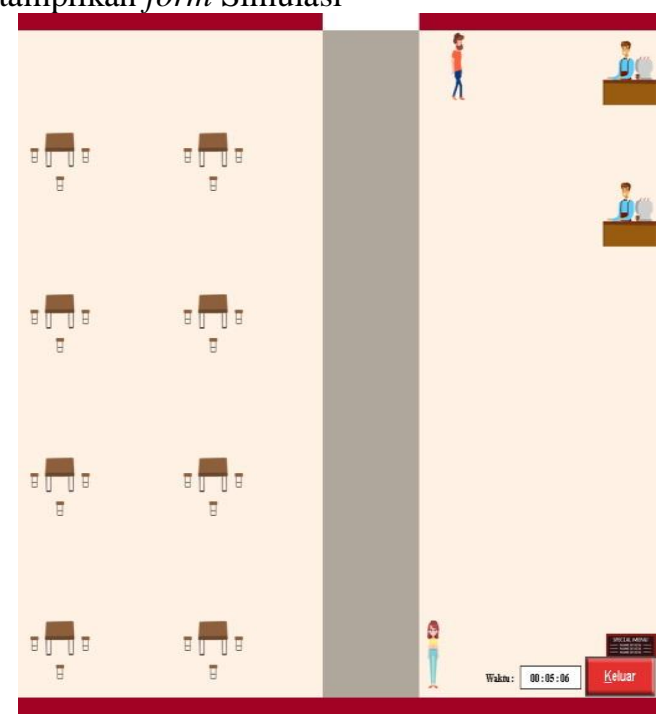

Gambar 13. Tampilan Simulasi

\section{PENUTUP}

Berdasarkan hasil yang didapatkan maka kesimpulan yang dapat diberikan sebagai berikut:

1. Perangkat lunak dapat mensimulasikan proses kerja antrian di rumah makan secara jelas dan interaktif, sehingga dapat digunakan sebagai ilustrasi mengenai sistem MQMS.

2. Perangkat lunak menampilkan tabel data proses simulasi yang berisi rincian proses simulasi yang dapat digunakan untuk membantu pengamatan proses simulasi.

3. Perangkat lunak dapat digunakan untuk membandingkan beberapa keadaan yang berbeda dengan mengatur keadaan awal dari proses simulasi melalui fasilitas „Pengaturan ${ }^{c e}$. 
Adapun berbagai saran untuk melengkapi kesimpulan yang diambil adalah sebagai berikut :

1. Simulasi dirancang agar mendekati keadaan sebenarnya, yaitu dengan menambahkan animasi yang lebih kompleks.

2. Perangkat lunak dapat dikembangkan dengan memperbanyak jumlah kasir pada rumah makan.

3. Perangkat lunak dapat dikembangkan lagi dengan menambahkan fitur yang memungkinkan customer untuk berpindah antrian ke kasir lainnya.

\section{DAFTAR PUSTAKA}

[1] Tari Saputri, Cahyadi Nugraha, Khuria Amila, Model Simulasi Untuk PergerakanKendaraan Pada Ruang Dua Dimensi Kontinu Dengan Pendekatan Pemodelan Berbasis Agen, Jurnal Online Institut Teknologi Nasional, No. 4 Vol. 2, 2014.

[2] Antono,Summy Dwi, Penerapan Model Simulasi pada Antrian di bagian pengobatan puskesmas Prambon Kabupaten Jeruk Nganju - Jurnal Penelitian Kesehatan Suara Flores.Vol.1.No.4.

[3] Jerry. (2015). “Discrete Simulation.”,Prentice Ha Series in Industrial Enginering. Page 377.

[4] Elis. (2015). "Model Ant Dengan Gangguan Pela Pola Kedatangan Berkelo IX No 1 Halaman 222-223.

[5] Saidi Ramadan Siregar, Simulasi Penerapan Multiple Queue Multiple Server Pada Antrian Bank Dengan Metode Discrete Event Simulation, MEANS (Media Informasi Analisa dan Sistem), ISSN: 2548-6985, Vol 1 No. 2, 2016. 